\title{
Branch elongation and diameter growth were temporally dissociated in "cerrado" tree species
}

\author{
Davi Rodrigo Rossatto ${ }^{1}$
}

Recebido: 06.11.2008; aceito: 23.07.2009

\begin{abstract}
Branch elongation and diameter growth were temporally dissociated in "cerrado" tree species). Here is a communicating about time differences between branch and diameter growth in a tree community of ten species in Neotropical savanna ("cerrado") of Central Brazil. This work was conducted to study branch expansion and diameter growth in a period of one year between 2006 and 2007. Branch growth had begin in middle dry season and had the peak occurrence during the dry period in September, while diameter growth had begin in late dry season and peaked in the middle of wet season in December. The majority of species followed the same pattern. Branch growth did not have relation with rainfall, while diameter growth had a clear and positive relation with rainfall records. These results suggested that branch growth was not depend on rainfall but only on water status recover, while diameter growth probably depends strongly on water and to carbon assimilation that occurs after branch and leaf expansion.
\end{abstract}

Key words: "cerrado", growth, rainfall, stem diameter growth

RESUMO - (O crescimento diamétrico e dos ramos são temporalmente separados em espécies arbóreas do cerrado). São apresentadas aqui diferenças temporais entre o crescimento de ramos e o crescimento diamétrico em uma comunidade de 10 espécies arbóreas do cerrado no Brasil Central. O estudo foi conduzido para se avaliar o alongamento dos ramos e o crescimento diamétrico num período de um ano, entre 2006 e 2007. O crescimento dos ramos teve início durante a estação seca e teve seu pico de ocorrência ainda no período seco em setembro; enquanto o crescimento em diâmetro se iniciou no final da estação seca e teve um pico durante o período chuvoso, em dezembro. A maior parte das espécies apresentou o mesmo comportamento. $\mathrm{O}$ crescimento de ramos não teve relação com a pluviosidade, enquanto para o crescimento diamétrico houve uma clara e positiva relação com os registros de pluviosidade. Os resultados indicam que o crescimento em ramo não é dependente da pluviosidade, mas sim da recuperação do status hídrico interno da planta, enquanto o crescimento em diâmetro é dependente da presença da chuva e da assimilação de carbono, que ocorre apenas após a expansão dos ramos e produção de novas folhas.

Palavras-chave: cerrado, crescimento, crescimento diamétrico, pluviosidade

\section{Introduction}

Neotropical savannas of Brazil, locally known as "cerrado", covers about 2 million $\mathrm{km}^{2}$, which makes it the second most extensive plant formation in South America. "Cerrado" communities are very complex and characterized by high tree species diversity (Eiten 1972) and by higher diversity of life forms as herbs, shrubs, grasses and sub-shrubs (Gottsberger \& Silberbauer-Gottsberger 2006). The distribution of the biome is determined by soil fertility, drainage and seasonal precipitation (Furley 1999, Durigan et al. 2003). Most of the "cerrado" soils are dystrophic, with low $\mathrm{pH}$, low availability of calcium and magnesium, also possessing high aluminum concentrations (Haridasan 1992). Seasonal precipitation is characterized by two distinct seasons: one very strong dry season during the southern winter and a wet season in summer, being the most important factor determining many aspects of anatomical and physiological properties of "cerrado" plant species (Franco 2002).

Plant carbon balance and growth are intimately related to the patterns of leaf flush and senescence (Reich 1995), so plants growing in seasonal environments must adjust their morphology and the activity of their branches to renewal structures and maximize their survival and productivity. The understanding of these adaptive features is crucial to identify the ecological strategies of plants concerning carbon assimilation and the use of water resources in relation to environmental constraints (Eamus 1999).

1. Universidade de Brasília, Instituto de Ciências Biológicas, Departamento de Botânica, Laboratório de Fisiologia Vegetal, Caixa Postal 04457, 70919-970 Brasília-DF, Brazil.drrossatto@unb.br 
In highly seasonal environments, such as "cerrado" regions there should be a strong selective pressure acting upon the timing of growth and leaf production to maximize survival and productivity (Meloche \& Diggle 2001).

Phenological studies of "cerrado" and other savanna formations in the world have allowed the description of the periodicity of leaf emergence and fall (Franco 1998, Williams et al. 1997, Prior et al. 2004) and some aspects about the dynamics of diameter growth (Hoffmann 2002, Prior et al. 2004), however there are no studies about the relation of branch expansion and diameter growth.

In the present study it is described the dynamics of branch and diameter growth in a community of ten tree species in a "cerrado" region of Central Brazil. The questions raised in the present study are: branch and diameter growth occurs during all months of the year? Branch and diameter growth occurs in the same period of time? Are these parameters influenced by rainfall? Does the studied species follow the same patterns?

\section{Material and methods}

Study site and selected species - This study was carried out at Ecological Reserve of IBGE (Instituto Brasileiro de Geografia e Estatística) near the city of Brasília in the Federal District, Brazil, located at 15 $56^{\circ} 41^{\prime \prime} S$ and $47^{\circ} 53^{\prime} 07^{\prime \prime} \mathrm{W}$. The average annual rainfall recorded at the meteorological station of IBGE from 1993-2002 was $1,462 \mathrm{~mm}$, with a distinct dry season from May to September and a mean annual temperature of 22.5 ${ }^{\circ} \mathrm{C}$. Rainfall and temperature records (figure 1) were obtained in meteorological station of IBGE. The wet

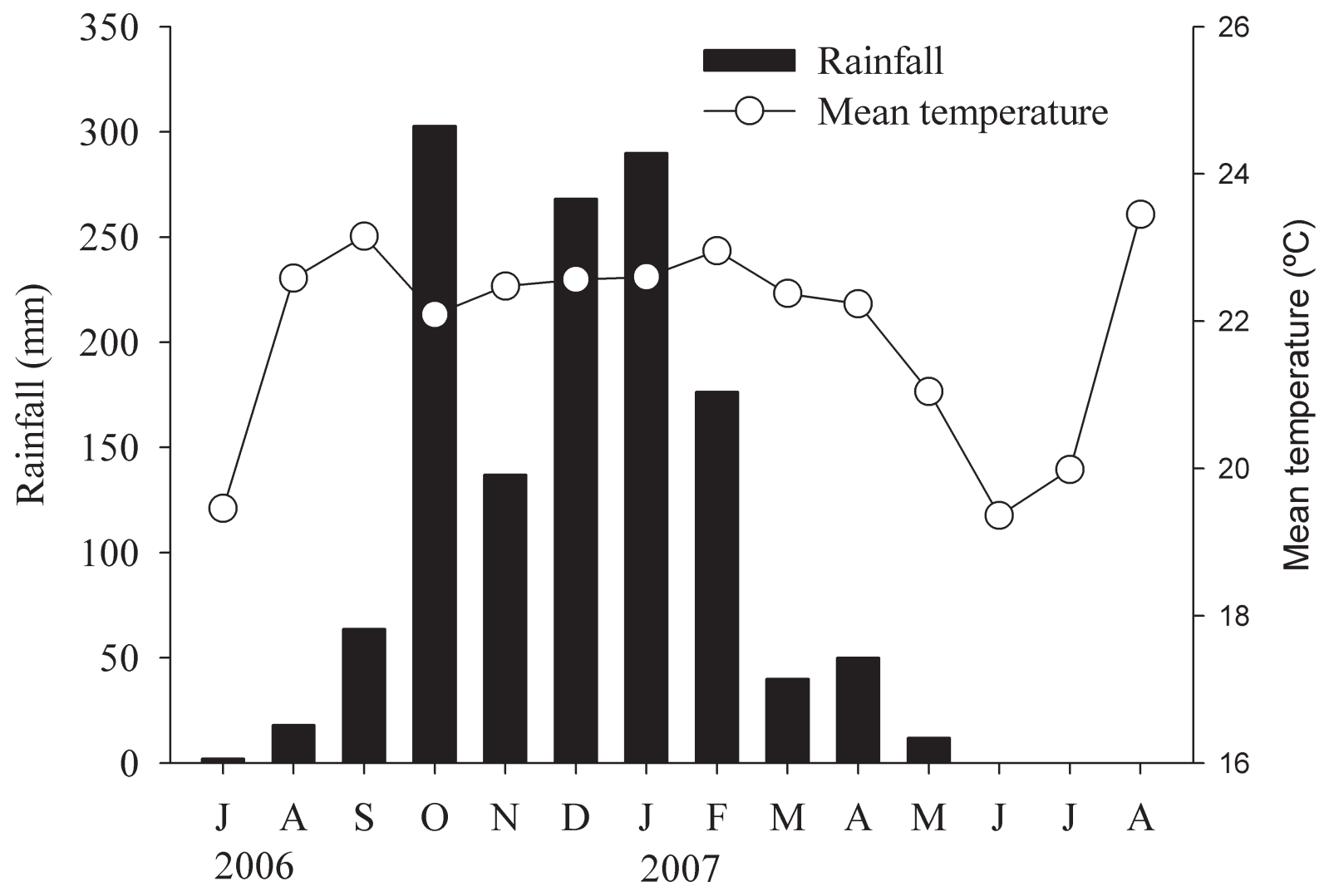

Figure 1. Seasonal changes in monthly rainfall and mean temperature during the study period (July 2006 to August 2007 ) at Reserva Ecológica do IBGE, Brasília-DF, Brazil. 
season of 2006-2007 occurred between October and February, where rainfall records were higher than $50 \mathrm{~mm}$. Ten most common "Cerrado" species (Silva Junior 2005) were chosen in May 2006 based on availability at the study site (table 1 ). For each species were sampled five individuals with similar height, with basal diameter around $7 \mathrm{~cm}$.

Branch and diameter growth - In July 2006 five previously developed branches were selected and marked with colored wires. In this work branch was defined as the region comprehended between apical meristem and first bifurcation. Measurements of branch length were taken monthly, with a digital caliper (Mitutoyo ${ }^{\circledR}$ ) with a resolution of $0.01 \mathrm{~mm}$ to verify the dynamics of branch expansion. This methodology was applied in a study of branch growth in other "cerrado" species Roupala montana Aubl. (Franco 1998). For more details about the application of this methodology see Rossatto \& Franco (2008).

Band dendrometers were used to measure monthly increments in stem circumference. The dendrometers were made manually with stainless steel ribbons and a stainless steel spring, as described by Cattelino et al. (1986). They were mounted at $30 \mathrm{~cm}$ from the ground, except where stem irregularities required installation slightly above or below this height. Dendrometers were installed in May 2006, three months before the initial measurements, to allow for stabilization. Measurements were performed approximately in the middle of the month from August 2006 to July 2007 (considered as an annual period of measurement), always in the morning to avoid problems associated with daily fluctuations in stem diameter due to changes in plant water status. The measurements were taken with a digital caliper (Mitutoyo $\AA$ ) with a resolution of $0.01 \mathrm{~mm}$. To convert circumference growth into diameter increments, all values were divided by $\pi$, as the stems were approximately circular in crosssectional area. Branch and diameter growth were accessed in the same trees.

The monthly values of branch and diameter growth were utilized to access the peak occurrence of the studied phenological patterns. For this purpose it was subtracted the value of branch or diameter growth in $(x)$ month to the value of $(x-1)$ month and the result was divided by the maximum value of branch or diameter growth in final month of observation (table 1). This value was multiplied by 100 to obtain a percentage indicator. This indicator was calculated to each study tree of each species, and the mean of species was utilized in statistical analysis to verify if the peak occurrence of branch and diameter growth differed at community level.

Statistical analysis - To test whether branch and diameter growth percentages at community level occurred uniformly throughout the year or in a specific period of the year for "cerrado" species, it was applied the Rayleigh test (Zar 1999). In this analysis, the timing of annual cycle is represented as angles of a circle, with January $1^{\text {st }}$ corresponding to $0^{\circ}$, February $1^{\text {st }}$ corresponding to $30^{\circ}$, etc. To test for differences between branch and diameter growth in the mean dates of their occurrence, it was applied the Watson-Williams test (Zar 1999) to data from July 2006 to June 2007, considered as the annual cycle.

Table 1. Tree species utilized in this study and annual branch and diameter growth values. Means followed by standard deviation $(\mathrm{n}=5)$.

\begin{tabular}{llcc}
\hline \multicolumn{1}{c}{ Species } & \multicolumn{1}{c}{ Family } & $\begin{array}{c}\text { Annual branch growth } \\
(\mathrm{cm})\end{array}$ & $\begin{array}{c}\text { Annual diameter growth } \\
(\mathrm{cm})\end{array}$ \\
\hline Byrsonima crassa Nied. & Malpighiaceae & $2.78(0.45)$ & $0.205(0.85)$ \\
Guapira noxia (Netto) Lundell & Nyctaginaceae & $8.76(0.45)$ & $0.140(0.90)$ \\
Hymenaea stigonocarpha Mart. ex Hayne & Fabaceae & $2.89(0.35)$ & $0.118(0.36)$ \\
Miconia pohliana Cogn. & Melastomataceae & $16.51(0.90)$ & $0.650(1.45)$ \\
Myrcia tomentosa (Aubl.) DC. & Myrtaceae & $7.82(1.20)$ & $0.520(0.50)$ \\
Myrsine guianensis (Aubl.) Kuntze & Myrsinaceae & $2.73(0.80)$ & $0.212(1.45)$ \\
Styrax ferrugineus Nees \& Mart. & Styracaceae & $5.20(0.95)$ & $0.203(1.20)$ \\
Symplocos rhamnifolia A. DC. & Symplocaceae & $6.42(0.45)$ & $0.322(0.45)$ \\
Tabebuia ochracea (Cham.) Standl. & Bignoniaceae & $2.17(0.14)$ & $0.217(0.14)$ \\
Vochysia thyrsoidea Pohl & Vochysiaceae & $16.55(0.85)$ & $0.295(2.15)$ \\
\hline
\end{tabular}


Relationships between the obtained data and climatic variables were made utilizing a simple non-parametric correlation (Spearman coefficient). In all this analysis was utilized the significance of 0.05 .

\section{Results}

Branch growth started during the dry period in July 2006 (figure 2A), while diameter growth in "cerrado" tree species initiated in the late dry season in September 2006 (figure 2B). Branch growth was not uniformly distributed throughout the year $(\mu=$ $\left.254.78^{\circ} ; \mathrm{z}=40.28 ; P<0.01\right)$, which indicates that this phenomenon occur in a specific period of the year, peaking during the end of dry season, about September (figure 2A). Diameter growth also had a non-uniformly distribution $\left(\mu=337.69^{\circ} ; \mathrm{z}=54.08\right.$; $P<0.01$ ), peaking in December 2006 (figure 2B), during middle wet season. Peak occurrence to branch expansion and to diameter growth differed in the time of occurrence $(\mathrm{F}=123.64 ; P=0.0001)$.

The majority of individual species followed the same pattern observed to the entire community (figure 2) to branch and diameter growth (figure 3), while some species have had different behavior, like Myrsine guianensis that elongated branches and increased diameter at the same time. Miconia pohliana had the same pattern observed here at community level, but to branch production had a second period of growth, after the break in diameter growth. A great variability was encountered to the annual branch and diameter growth, as can be seen in table 1 .

Branch elongation was not correlated to monthly rainfall (Spearman rank correlation $=0.01, P>0.20$, $\mathrm{n}=12$ ), however there as clear correlation between mensal diameter growth and monthly rainfall to the studied community trees (Spearman rank correlation $=0.60, \mathrm{P}=0.0002, \mathrm{n}=12$ ).

\section{Discussion}

Tree community species studied here started branch elongation at the middle of the dry season, in July. The observed patterns to branch growth here were in general similar with that was found for tree species growing in a seasonal area of Himalaya (Negi 2006), being also very similar for tree species in a subtropical seasonal North America Savanna
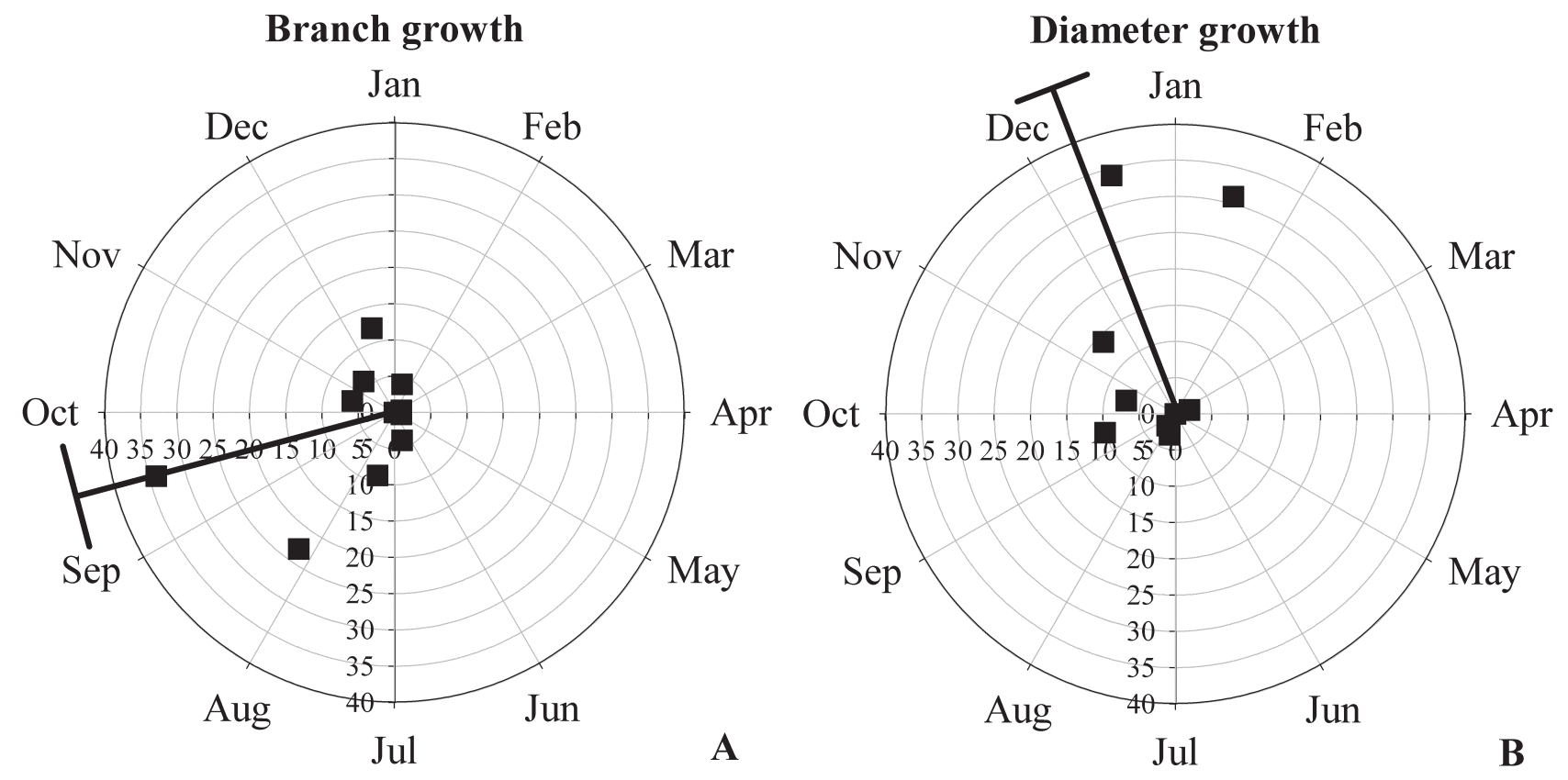

Figure 2. Patterns of branch (A) and diameter (B) growth for the studied community of "cerrado" tree species. Arrows represent the mean angle for phenological patterns to the period of July 2006 to June 2007. $=\%$ of total growth in each month at community level. 
(Nelson et al. 2002). The elongation of branches and the production of new leaves during the dry months contribute to maximize the leaf carbon uptake after dry season period, so tree can quickly achieve full crown development and maximal carbon gain when the first rains begin (Franco et al. 2005).

Correlation between branch elongation and rainfall were expected in some seasonality areas around the world (Palacio \& Montserrat-Martí 2005) because branch elongation were a direct result of meristem differentiation, being necessary the presence of water to make hydration and initiate the bud break and posterior elongation (De Fäy et al. 2000). Researches working in some savannas around the world related that leaf flush were not correlated with precipitation (Damascos et al.2005), however present a major influence to an increase of about 30 or less minutes in day-length (Rivera et al. 2002).

Physiological adjustments could be acting in "cerrado" trees to maintain or recover their internal water status, necessary to elongate branches and produce new leaves during the dry season. The mechanisms involved in this recover could be related to the influence of deep roots in "cerrado" tree species (Jackson et al. 1999, Goldstein et al. 2008) or the hydraulic redistribution by roots during dry season (Scholz et al. 2008a), which could propitiate adequate water availability to branch expansion. Also most of savanna trees have a reduction of total leaf area per plant during dry months (Goldstein et al. 2008), which clearly reduces transpiration and propitiates the maintenance of their water status (Reich \& Borchert 1984, Williams et al. 1997).

Diameter growth had begin between the end of dry season and beginning of wet season (September to October), however the trees had higher increase in growth at higher rainfall months (figure 2B). The delayed diameter growth in relation to branch growth during wet season could be due to higher water availability during this season, because diameter growth was correlated to rainfall records and generally are very sensitive to soil water content variation (Scholz et al. 2008b). The sensitiveness to soil water content may be the cause of diameter decline in some species as Hymenaea, Vochysia and Byrsonima (figure 3).

Diameter growth in "cerrado" species was clearly affected by productivity parameters such specific leaf area (Rossatto et al.2009) and in other savannas of the world also influenced by carbon assimilation rates in mass basis (Prior et al. 2004), so another possibility is that diameter increased after branch elongation because the maximal leaf canopy cover appears only after the branch elongation and leaf production. Branch elongation and leaf production were tightly correlated processes in "cerrado" tree species (Rossatto et al. 2009). The maximal canopy cover could lead to maximal carbon assimilation, which had been occurring in lower intensity since the dry months (Franco et al. 2005), and now could be investment in trunk growth.

The annual diameter growth observed here to "cerrado" species, between $0.118-0.650 \mathrm{~cm}$, were very low in comparison to gallery forest tree species (about $1-2.4 \mathrm{~cm}$ ) (Felfili 1995) and other vegetation types $(1-4 \mathrm{~cm})$ (Prior et al. 2004), which suggest that carbon assimilates were being diverted to carbohydrate stores and/or root growth. Overall "cerrado" tree species invest more carbon in roots and reserves (Castro \& Kauffman 1998, Paulilo \& Felippe 1998, Hoffmann \& Franco 2003), being an adaptive strategy allowing them to resprout after a fire event (Hoffmann \& Moreira 2002).

The variability in total branch and diameter growth between the species (table 1) could be related to individual characteristics of them, because branch and diameter growth had been strongly explained by phylogeny rather than by environmental characteristics (Rossatto et al. 2009); while the time behavior had been very similar to the majority of species. This tendency was also found in other studies of branch and diameter growth (Damascos et al. 2005, Prior et al. 2004).

The data presented here demonstrate that branch and diameter growth were temporally dissociated in "cerrado" tree species because diameter growth was very dependent to water presence and also probably to carbon assimilation that occurs with more intensity after branch expansion and leaf production during the dry season. This study also demonstrates that the observed patterns could be variable in some species of a given community.

\section{Acknowledgments}

The author would like to thank Coordenação de Aperfeiçoamento do Ensino Superior (CAPES), Conselho Nacional de Ciência e Tecnologia (CNPq) and National Science Foundation (NSF) for the financial support; Dr. Augusto César Franco, Dr. William Arthur Hoffmann and two anonymous reviewers for suggestions and helpful comments in this study. 

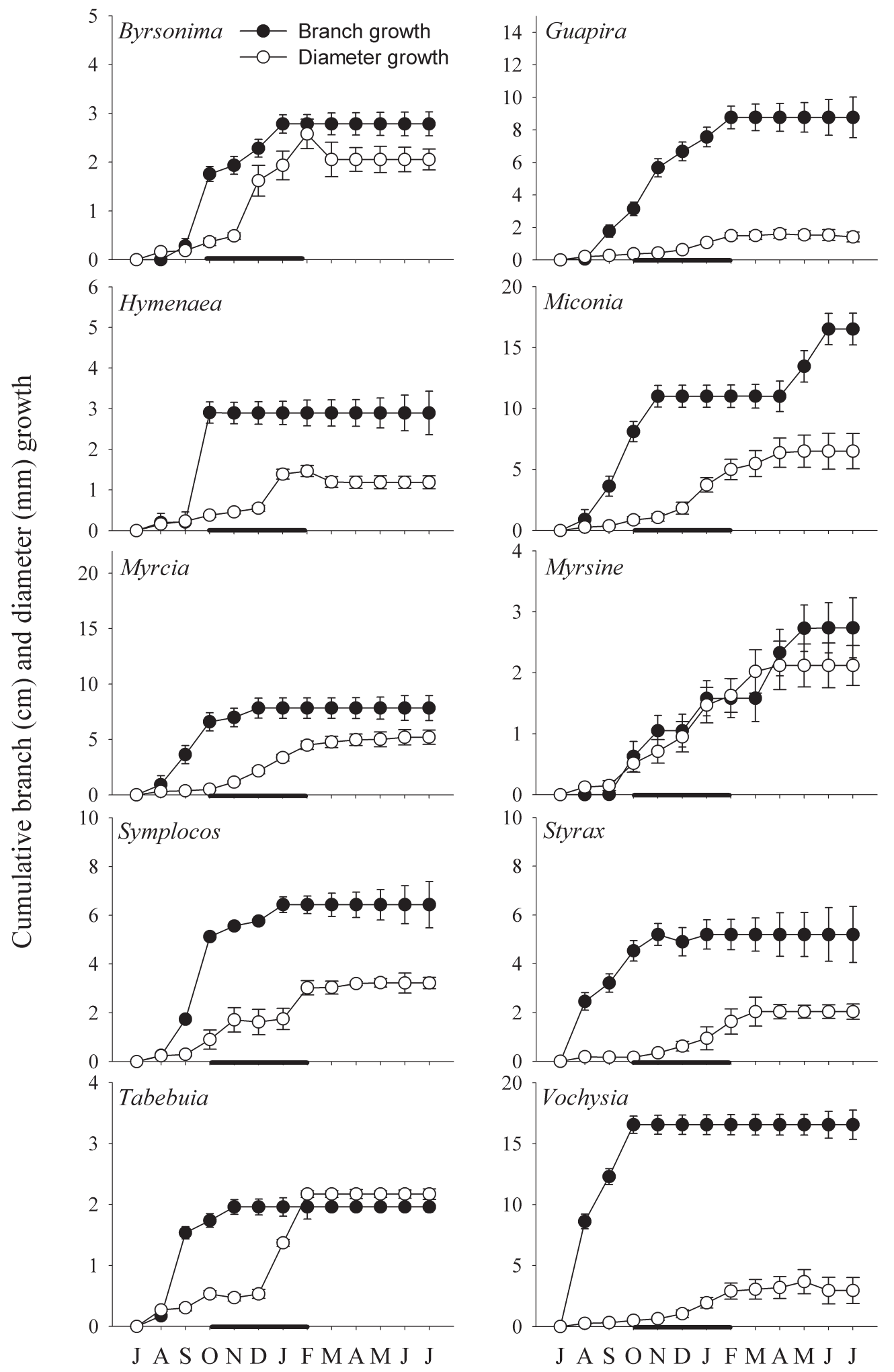

Figure 3. Cumulative branch and diameter growth of ten "cerrado" tree species. Horizontal bar indicates the wet period. Vertical bars indicate standard error $(n=5)$. 


\section{Literature cited}

Castro,E.A.\& Kauffman, J.B. 1998. Ecosystem structure in the Brazilian cerrado: a vegetation gradient of aboveground biomass, root mass and consumption by fire. Journal of Tropical Ecology 14: 263-283.

Cattelino, P.J., Becker, C.A. \& Fuller, L.G. 1986. Construction and installation of homemade dendrometer bands. Northern Journal of Applied Forest 3: 73-75.

Damascos, M.A., Prado, C.H.B.A. \& Ronquim, C.C. 2005. Bud composition, branching patterns and leaf phenology in Cerrrado woody species. Annals of Botany 96: 1075-1108.

De Fäy, E., Vacher, V. \& Humbert, F. 2000. Water-related phenomena in winter buds and twigs of Picea abies L. until bud-burst: a biological, histological and NMR study. Annals of Botany 86: 1097-1107.

Durigan, G., Ratter, J.A., Bridgewater, S., Siqueira, M.F. \& Franco, G.A.D.C. 2003. Padrões fitogeográficos do cerrado paulista sob uma perspectiva regional. Hoehnea 35: 39-51.

Eamus, D. 1999. Ecophysiological traits of deciduous and evergreen woody species in the seasonally dry tropics. Trends in Ecology and Evolution 14: 11-16.

Eiten, G. 1972. The cerrado vegetation of Brazil. Botanical Review 38: 201-349.

Franco, A.C. 1998. Seasonal patterns of gas exchange, water relations and growth of Roupala montana, an evergreen savanna species. Plant Ecology 136: 69-76.

Franco,A.C. 2002. Ecophysiology of woody plants. In: P.S. Oliveira \& R.J. Marquis (eds.). The Cerrados of Brazil: ecology and natural history of a neotropical savanna. Columbia University Press, New York, pp. 178-197.

Franco, A.C., Bustamante, M., Caldas, L.S., Goldstein, G., Meinzer, F.C., Kozovits, A.R., Rundel, P. \& Coradin,V.T.R. 2005. Leaf functional traits of Neotropical savanna trees in relation to seasonal water deficit. Trees 19: 326-335.

Furley, P.A. 1999. The nature and diversity of neotropical savanna vegetation with particular reference to the Brazilian cerrado. Global Ecology and Biogeography 8: 223-241.

Goldstein, G., Meinzer, F.C., Bucci, S.J., Scholz, F.G., Franco, A.C. \& Hoffmann, W.A. 2008. Water economy of Neotropical savanna trees: six paradigms revisited. Tree Physiology 28: 395-404.

Gottsberger, G. \& Silberbauer-Gottsberger, I. 2006. Life in the cerrado: a South America tropical seasonal ecosystem. v. 1. Origin, structure, dynamics and plant use. Reta Verlag, Ulm.

Haridasan, M. 1992. Observations on soils, foliar nutrient concentrations and floristic composition of cerrado sensu stricto and cerradão communities in central Brazil. In: P.A. Furley, J. Proctor \& J. Ratter (eds.). Nature and dynamics of forest-savanna boundaries. Chapman and Hall, London, pp. 171-184.

Hoffmann, W.A. 2002. Direct and indirect effects of fire on radial growth of cerrado savanna trees. Journal of Tropical Ecology 18: 137-142.

Hoffmann, W.A. \& Franco, A.C. 2003. Comparative growth analysis of tropical Forest and savanna woody plants using phylogenetically-independent contrasts. Journal of Ecology 91: 475-484.

Hoffmann, W.A.\& Moreira,A.G. 2002. The role of fire in population dynamics of woody plants $I n$ : P.S. Oliveira \& R.J. Marquis (eds.) The Cerrados of Brazil: ecology and natural history of a neotropical savanna. Columbia University Press, New York, pp. 159-177.

Jackson, P.C., Meinzer, F.C., Bustamante, M.M.C., Goldstein, G., Franco, A.C., Rundel, P.W., Caldas, L.S., Igler, E. \& Causin, F. 1999. Partitioning of soil water among tree species in a Brazilian cerrado ecosystem Tree Physiology 19: 717-724.

Meloche, C.G. \& Diggle, P.K. 2001. Preformation, architectural complexity and developmental flexibility in Acomastylis rossii (Rosaceae). American Journal of Botany 88: 115-129.

Negi, G.C.S. 2006. Leaf and bud demography and shoot growth in evergreen and deciduous trees of central Hymalaya, India. Trees 20: 416-429.

Nelson, J.A., Barnes, P.W. \& Archer, S. 2002. Leaf demography and growth to altered resource availability in woody plants of contrasting leaf habit in a subtropical savanna. Plant Ecology 160: 193-205.

Palacio, S. \& Monsteserrat-Martí, G. 2005. Bud morphology and shoot growth dynamics in two species of Mediterranenan sub-shrubs co-existing in Gypsum outcrops. Annals of Botany 95: 949-958.

Paulilo, M.T.S. \& Felippe, G.M. 1998. Growth of the shrub-tree flora of the Brazilian cerrados: A review. Tropical Ecology 39: 165-174.

Prior, L.D., Eamus, D. \& Bowman, D.M.J.S. 2004. Tree growth rates in north Australian savanna habitats: seasonal patterns and correlations with leaf attributes. Australian Journal of Botany 52: 303-314.

Reich, P.B. \& Borchert, R. 1984. Water stress and tree phenology in a tropical dry forest in the Lowlands of Costa Rica. Journal of Ecology 72: 61-74.

Reich, P.B. 1995. Phenology of tropical forests: patterns, causes and consequences. Canadian Journal of Botany 73: $164-174$.

Rivera, G., Elliot, S., Caldas, L.S., Nicolossi, G., Coradin, V.T.R. \& Borchert, R. 2002. Increasing daylenght induces spring flushing in tropical dry forest trees in the absence of rain. Trees 16: 445-456.

Rossatto, D.R. \& Franco, A.C. 2008. Expansão e mortalidade de ramos em espécies arbóreas do cerrado sensu stricto. Revista Brasileira de Botânica 31: 717-721. 
Rossatto, D.R., Hoffmann, W.A. \& Franco, A.C. 2009. Differences in growth patterns between co-occuring forest and savanna trees affect the forest-savanna boundary. Functional Ecology 23: 689-698.

Scholz, F.G., Bucci, S.J., Goldstein, G., Moreira, M.Z., Meinzer,F.C.,Domec,J.C., Villalobos-Vega,R., Franco, A.C. \& Miralles-Wihelm, F. 2008a. Biophysical and life-history determinants of hydraulic lift in Neotropical savanna trees. Functional Ecology 22: 773-786.

Scholz, F.G., Bucci, S.J., Goldstein, G., Meinzer, F.C., Franco, A.C. \& Wilhelm, F.M. 2008b. Temporal dynamics of stem expansion and contraction in savanna trees: withdrawal and recharge of stored water. Tree Physiology 28: 469-480.

Silva Junior, M.C. 2005. 100 Árvores do cerrado: guia de campo. Rede de Sementes do Cerrado, Brasília.

Williams, R.J., Myers, B.A., Muller, W.J., Duff, G.A. \& Eamus, D. 1997. Leaf phenology of woody species in a north Australian tropical savanna. Ecology 78: 2542-2558.

Zar, J.H. 1999. Biostatistical analysis. Prentice Hall, Englewood Cliffs. 